\title{
Energy consumption in non-reproducing adults of the eastern hedgehog Erinaceus concolor
}

\author{
Elżbieta KRÓL*
}

\begin{abstract}
Król E. 1994. Energy consumption in non-reproducing adults of the eastern hedgehog Erinaceus concolor. Acta theriol. 39: 339-344.

Energy balance and body mass changes were studied in non-reproducing adult eastern hedgehogs Erinaceus concolor (Martin, 1838) during an 8-day feeding trial. The amount of energy consumed by the hedgehogs that maintained constant body mass averaged $0.74 \mathrm{~kJ} \times \mathrm{g}^{-1} \times \mathrm{day}^{-1}$. The energy equivalent of body mass loss

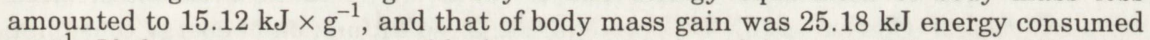
$\times \mathrm{g}^{-1}$. If the energy contents of body mass gained and lost were the same, biomass production efficiency was $72.2 \%$.
\end{abstract}

Department of Ecosystems Studies, Jagiellonian University, Ingardena 6, PL 30-060 Kraków, Poland

Key words: Erinaceus concolor, digestibility coefficient, costs of maintenance, energy equivalents of body mass changes

\section{Introduction}

Hedgehogs of the genus Erinaceus share characteristics that have been interpreted as energy-saving strategies. These include a nocturnal niche (Crompton et al. 1978), using spines to reduce predation (McNab 1986), the ability to enter torpor during the whole active season (Fowler 1988), and long hibernation (Dmi'el and Schwarz 1984). However, the hedgehog's energetics, especially the economics of energy allocation, is relatively little known. There is only scattered data on their metabolic rates, regarding the European hedgehog E. europaeus (e.g. Hildwein and Malan 1970, Shkolnik and Schmidt-Nielsen 1976, Tähti 1978, McNab 1980). The energetics of the two remaining species of Erinaceus apparently has never been studied.

The eastern hedgehog Erinaceus concolor (Martin, 1838) is a sibling species of E. europaeus, inhabiting a range extending from Eastern Europe (about $14^{\circ} \mathrm{E}$ ) to the River $\mathrm{Ob}$ (about $80^{\circ} \mathrm{E}$ ), north to about $60^{\circ} \mathrm{N}$ in Russia and West Siberia, and south to Israel and Northern Iran (Corbet 1988, Frost et al. 1991). This paper, which is part of a larger study on the total energy budget of the eastern hedgehog

* Present address: Bee Research Department, Agricultural University, Al. 29 Listopada 52, PL 31-425 Kraków, Poland 
(Król 1992), reports on the energy requirements of non-reproducing adults, as measured by the food balance method.

\section{Material and methods}

Hedgehogs were captured in Cracow $\left(50^{\circ} \mathrm{N}, 20^{\circ} \mathrm{E}\right)$ in the spring of 1989 . The animals, housed outdoors, were exposed to natural photoperiods and temperature, and fed and watered ad libitum. Five adult, non-reproducing individuals ( 3 females and 2 males) were used for this experiment. Four days before the experimental trial, the hedgehogs were put on a homogenous diet of cooked horsemeat, cornflakes and carrots in weight proportions of $20: 1: 1$. This food contained $59.6 \%$ water and $26.53 \mathrm{~kJ}$ energy per gram dry mass.

The experiment was conducted in June and lasted 8 days. The animals were placed in pens $(2 \times$ $3 \times 1 \mathrm{~m}$ each) lined with polyethylene sheeting and covered with wire netting $(1 \mathrm{~cm} \mathrm{mesh})$, which allowed collection of the uneaten food and faeces. Wooden nest boxes $(90 \times 70 \times 60 \mathrm{~cm})$ were provided in the pens. Every day between 19.30 and 20.30 the animals were weighed, uneaten food and faeces were collected, and fresh food was supplied in excess. The uneaten food and faeces were oven-dried at $105^{\circ} \mathrm{C}$ and weighed, and samples were combusted in an adiabatic bomb calorimeter KL-3 ("Precyzja", Bydgoszcz) (Górecki 1975). This procedure allowed estimation of energy consumption $(C)$, energy losses in faeces $(F)$, and digestibility coefficient $((C-F) / C)$ (Drożdż 1975). The values of $C$ and $F$ are expressed in kJ per unit of time.

Relationship between energy consumption and body mass changes was described by reduced major axis equations (Sokal and Rohlf 1981). In these equations (general form: $\mathrm{Y}=\mathrm{a}+\mathrm{v} y \cdot x \mathrm{X}$ ), the correlation coefficient $(r)$ and standard error of the slope $\left(s_{\mathrm{v}}\right)$ are also given; $n$ refers to the number of measurements taken and $N$ to the number of individuals used. Means are reported \pm SD. Differences between means were tested by one-way ANOVA (Sokal and Rohlf 1981).

\section{Results}

During the 8-day feeding trial the hedgehogs had considerable daily body mass changes $\left(\Delta M\right.$, range -36.5 to $+40.5 \mathrm{~g} \times$ day $\left.^{-1}\right)$ and different levels of daily energy consumption $\left(C\right.$, range 121.2 to $1596.8 \mathrm{~kJ} \times$ day $\left.^{-1}\right)$. These values were highly correlated, according to the reduced major axis equations fitted separately to energy consumption corresponding to negative and positive body mass changes (Fig. 1):

$$
\begin{aligned}
\text { for } \mathrm{DM} & <0 \\
\qquad C & =647.37+15.12 \Delta M \quad\left(n=16, N=5, r=0.98, s_{\mathrm{V}}=0.88\right),
\end{aligned}
$$

for $\mathrm{DM}>0$

$$
C=520.82+25.18 \Delta M \quad\left(n=24, N=5, r=0.93, s_{\mathrm{v}}=2.12\right) .
$$

The slope coefficients of these lines, which may be regarded as energy equivalents of body mass changes, show that burning $1 \mathrm{~g}$ of the animal's own tissues yielded $15.12 \mathrm{~kJ}$ energy (equation 1), whereas deposition of $1 \mathrm{~g}$ of body tissue required additional energy consumption of $25.18 \mathrm{~kJ}$ (equation 2). The hedgehogs that maintained constant body mass $\left(\Delta M \cong 0\right.$, range -1.6 to $+0.6 \mathrm{~g} \times$ day $\left.^{-1}\right)$ consumed $0.74 \pm 0.03 \mathrm{~kJ} \times \mathrm{g}^{-1} \times \mathrm{day}^{-1}(n=4, N=3)$. 


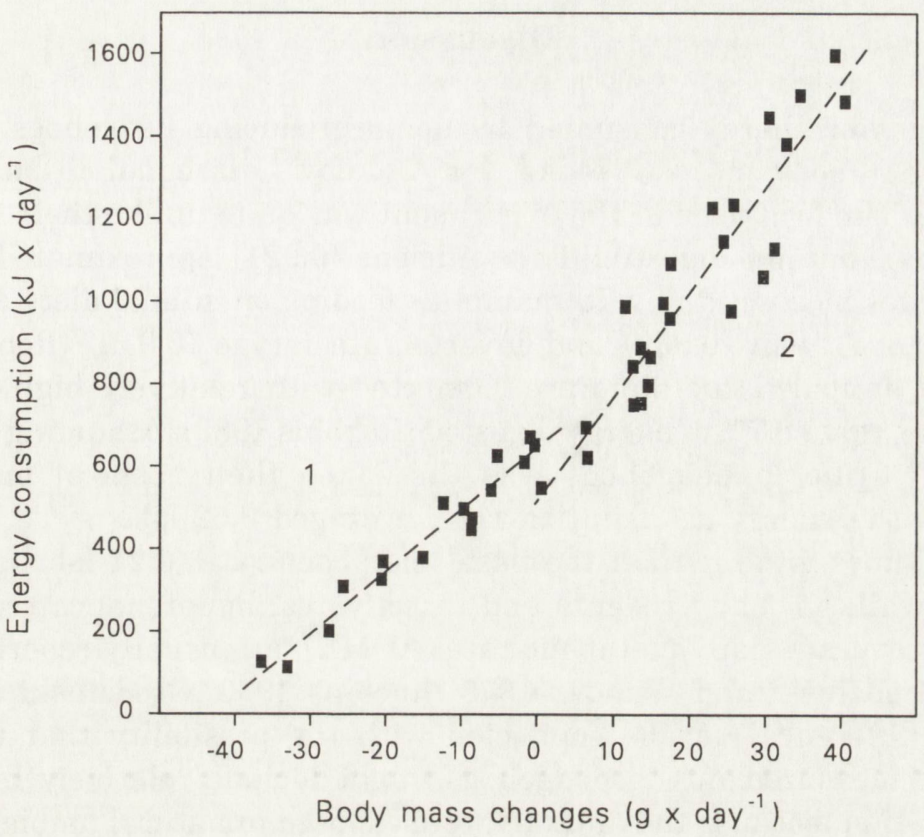

Fig. 1. Correlation between daily energy consumption $(C)$ and daily body mass changes $(\Delta M)$ in 5 eastern hedgehogs during an 8-day feeding trial. The equations for lines 1 and 2 are given in the text.

The caloric values of the faeces did not differ statistically between individuals

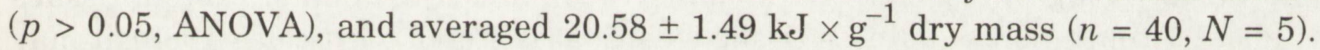
The digestibility coefficient amounted to $0.921 \pm 0.005(n=5, N=5)$ (Table 1).

Table 1. Energy consumption, energy loss in faeces and digestibility coefficient in 5 eastern hedgehogs during an 8-day feeding trial.

\begin{tabular}{|c|c|c|c|c|c|c|}
\hline \multicolumn{2}{|c|}{ Animal } & \multirow{2}{*}{$\begin{array}{l}\text { Initial } \\
\text { body } \\
\text { mass } \\
(\mathrm{g})\end{array}$} & \multirow{2}{*}{$\begin{array}{l}\text { Final } \\
\text { body } \\
\text { mass } \\
(\mathrm{g})\end{array}$} & \multirow{2}{*}{$\begin{array}{c}\text { Energy } \\
\text { consumption } \\
C \\
\text { (kJ/8 days) }\end{array}$} & \multirow{2}{*}{$\begin{array}{c}\text { Energy loss } \\
\text { in faeces } \\
F \\
\text { (kJ/8 days) }\end{array}$} & \multirow{2}{*}{$\begin{array}{c}\text { Digestibility } \\
\text { coefficient } \\
(C-F) / C \\
\text { (kJ/8 days) }\end{array}$} \\
\hline No & Sex & & & & & \\
\hline 1 & $\mathrm{~F}$ & 728.5 & 765.0 & 4936.2 & 394.9 & 0.920 \\
\hline 2 & $\mathrm{M}$ & 783.0 & 834.1 & 5391.2 & 404.3 & 0.925 \\
\hline 3 & $\mathrm{~F}$ & 782.5 & 865.0 & 6688.6 & 508.3 & 0.924 \\
\hline 4 & $\mathrm{~F}$ & 840.2 & 888.7 & 5674.5 & 499.4 & 0.912 \\
\hline 5 & M & 842.6 & 917.5 & 5781.7 & 445.2 & 0.923 \\
\hline Mean & & & & 5694.4 & 450.4 & 0.921 \\
\hline SD & & & & 644.8 & 52.4 & 0.005 \\
\hline
\end{tabular}




\section{Discussion}

The amount of energy consumed by non-reproducing hedgehogs that maintained constant body mass $\left(0.74 \mathrm{~kJ} \times \mathrm{g}^{-1} \times\right.$ day $\left.^{-1}\right)$ is equal to their costs of maintenance. The food used in the experiment was quite unlike their natural diet (invertebrates), but its digestibility coefficient (0.921) approximated the corresponding values measured in wild mammals feeding on animal diets of mammals and birds (0.894), fish (0.939) and invertebrate larvae (0.912) (Robbins 1983). High-protein animal-tissue diets are connected with relatively high energy loss through urine, up to $9.7 \%$ of energy digested (Robbins 1983). Assuming that energy loss through urine in hedgehogs was the same, their costs of maintenance, expressed as the energy assimilation rate, averaged $0.62 \mathrm{~kJ} \times \mathrm{g}^{-1} \times \mathrm{day}^{-1}$. This value is 2.9 times greater than the basal metabolic rate $\left(0.21 \mathrm{~kJ}^{\circ} \mathrm{g}^{-1} \times\right.$ day $^{-1}$; Król 1994), while in many rodents and insectivores, maintenance requirements, expressed as average daily metabolic rate (ADMR), are usually reported as twice BMR (e.g. Grodziński and Wunder 1975, Robbins 1983, Grodziński and Weiner 1984). This difference may be connected with the possibility that the costs of maintenance measured in the hedgehogs might include relatively high costs of thermoregulation, because the animals were exposed to natural ambient temperatures ranging from 9.2 to $25.1^{\circ} \mathrm{C}$, with a daily average of $16.4^{\circ} \mathrm{C}$ (Król 1992). Most ADMR measurements published so far have been taken at constant ambient temperature of $20^{\circ} \mathrm{C}$ (e.g. Grodziński and Wunder 1975, French et al. 1976).

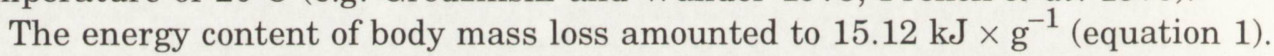
Since anhydrous body protein and fat in wild mammals comprise on average 22.72

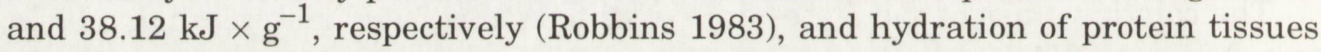
is about 7 times that of adipose tissue where fat is stored (Groscolas 1988), it may be assumed that body mass loss observed in the present experiment was based on depletion of body fat reserves. The energy content of body mass loss in hedgehogs $\left(15.12 \mathrm{~kJ} \times \mathrm{g}^{-1}\right)$ was similar to that reported for birds, Fringilla coelebs

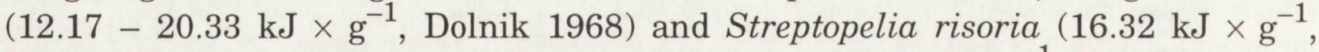
Brisbin 1969); and for rodents, Sigmodon hispidus (14.6 kJ $\times \mathrm{g}^{-1}$, Randolph et al.

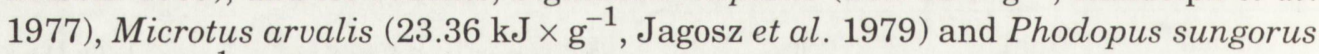
(19.3 kJ $\times \mathrm{g}^{-1}$, Weiner 1987).

The energy equivalent of body mass gain was $25.18 \mathrm{~kJ}$ energy consumed $\times \mathrm{g}^{-1}$ (equation 2), which after subtracting the energy value of faeces and urine corresponded to $20.95 \mathrm{~kJ}$ energy assimilated $\times \mathrm{g}^{-1}$. The corresponding values reported for Microtus arvalis and Rattus norvegicus are $35.86 \mathrm{~kJ}$ energy assimilated $\times \mathrm{g}^{-1}$ (Jagosz et al. 1979) and 13-20 kJ energy assimilated $\times \mathrm{g}^{-1}$ (Farrell and Williams 1989), respectively. The differences between these values probably depend on the composition of body mass gain, but neither study investigated it. On the other hand, it is known that deposition of $1 \mathrm{~kJ}$ protein and $1 \mathrm{~kJ}$ fat require on average 2.06 and $1.37 \mathrm{~kJ}$ assimilated energy, respectively (see Pullar and Webster 1977 for review). This means that the energy efficiency of protein 
depositicn amounts to $48.5 \%(1 \mathrm{~kJ} / 2.06 \mathrm{~kJ} \times 100)$, while that of fat deposition amounts to $73.0 \%(1 \mathrm{~kJ} / 1.37 \mathrm{~kJ} \times 100)$. In the hedgehogs, assuming that the energy contents of body mass gain and body mass loss were the same, biomass production efficiency was $72.2 \%(15.12 \mathrm{~kJ} / 20.95 \mathrm{~kJ} \times 100)$, suggesting deposition of fat tissue.

Acknowledgements: I thank J. Weiner, J. Staliński, P. Koteja and M. Jacobs for helpful comments on earlier drafts.

\section{References}

Brisbin I. L. 1969. Bioenergetics of nightly weight loss in a captive ring dove. The Oriole 34: 17-24.

Corbet G. B. 1988. The family Erinaceidae: a synthesis of its taxonomy, phylogeny, ecology and zoogeography. Mammal Rev. 18: 117-172.

Cromptcn A. W., Taylor C. R. and Jagger J. A. 1978. Evolution of homeothermy in mammals. Nature 272: 333-336.

Dmi'el R. and Schwarz M. 1984. Hibernation patterns and energy expenditure in hedgehogs from semi-arid and temperate habitats. J. comp. Physiol. B 155: 117-123.

Dolnik V. R. 1968. Caloric value of the daily variation of the body weight in birds. International Stucies on Sparrows 2: 89-96.

Drożdż A. 1975. Food habits and food assimilation in mammals. [In: Methods for ecological bioenergetics. W. Grodziński, R. Z. Klekowski and A. Duncan, eds]. Blackwell Scientific Publications, Oxford: 325-333.

Farrell D. J. and Williams V. J. 1989. Calorimetric measurements made on rats during repeated perieds of weight gain and weight loss. Comp. Biochem. Physiol. 94A: 61-67.

Fowler P. A. 1988. Thermoregulation in the female hedgehog, Erinaceus europaeus, during the breeting season. J. Reprod. Fert. 82: 285-292.

French N. R., Grant W. E., Grodziński W. and Swift D. M. 1976. Small mammal energetics in grassland ecosystems. Ecol. Monogr. 46: 201-220.

Frost D. R, Wozencraft W. C. and Hoffmann R. S. 1991. Phylogenetic relationships of hedgehogs and gymures (Mammalia: Insectivora: Erinaceidae). Smithsonian Contributions to Zoology No 518. Smithsonian Institution Press, Washington, D.C.: 1-69.

Górecki A. 1975. The adiabatic bomb calorimeter. [In: Methods for ecological bioenergetics. W. Grocziński, R. Z. Klekowski and A. Duncan, eds]. Blackwell Scientific Publications, Oxford: 281-288.

Grodzińtki W. and Weiner J. 1984. Energetics of small and large mammals. Acta zool. Fenn. 172: $7-10$

Grodzińıki W. and Wunder B. A., Jr 1975. Ecological energetics of small mammals. [In: Small manmals: their productivity and population dynamics. F. B. Golley, K. Petrusewicz and L. Ryszkowski, eds]. Cambridge University Press, Cambridge: 173-204.

Groscolas R. 1988. The use of body mass loss to estimate metabolic rate in fasting sea birds: a critical exanination based on emperor penguins (Aptenodytes forsteri). Comp. Biochem. Physiol. 90A: 361-366.

Hildweir G. and Malan A. 1970. Capacités thermorégulatrices du hérisson en été et en hiver en l'absence d'hibernation. Arch. Sci. Physiol. 24: 133-143.

Jagosz el, Górecki A. and Pozzi-Cabaj M. 1979. The bioenergetics of deposit and utilization of stored enersy in the common vole. Acta theriol. 24: 391-397.

Król E. 1992. [Energy budget of the eastern hedgehog Erinaceus concolor]. Unpubl. Ph. D. thesis. Jagitllonian University, Kraków: 1-115. [In Polish]

Król E. 994. Metabolism and thermoregulation in the eastern hedgehog Erinaceus concolor. J. comp. Physiol. B (in press). 
McNab B. K. 1980. Energetics and the limits to a temperate distribution in armadillos. J. Mammal. 61: $606-627$.

McNab B. K. 1986. The influence of food habits on the energetics of eutherian mammals. Ecol. Monogr. 56: 1-19.

Pullar J. D. and Webster A. J. F. 1977. The energy cost of fat and protein deposition in the rat. Br. J. Nutr. 37: 355-363.

Randolph P. A., Randolph J. C., Mattingly K. and Foster M. M. 1977. Energy costs of reproduction in the cotton rat, Sigmodon hispidus. Ecology 58: 31-45.

Robbins C. T. 1983. Wildlife feeding and nutrition. Academic Press, New York: 1-343.

Sokal R. R. and Rohlf F. J. 1981. Biometry. Second edn. W. H. Freeman and Company, New York: $1-859$.

Shkolnik A. and Schmidt-Nielsen K. 1976. Temperature regulation in hedgehogs from temperate and desert environments. Physiol. Zool. 49: 56-64.

Tähti H. 1978. Seasonal differences in $\mathrm{O}_{2}$ consumption and respiratory quotient in a hibernator (Erinaceus europaeus L.). Annls zool. Fenn. 15: 69-75.

Weiner J. 1987. Maximum energy assimilation rates in the Djungarian hamster (Phodopus sungorus). Oecologia 72: 297-302.

Received 16 May 1994, accepted 25 October 1994. 